\title{
The Genre Topoi of the Mass Literature in the Amur Writers Works at the Turn of XX-XXI Centuries
}

\author{
Natalia V. Kireeva* \\ Blagoveshchensk State Pedagogical University \\ 104 Lenina Str., Blagoveschensk, 675000, Russia
}

Received 10.01.2017, received in revised form 18.01.2017, accepted 29.04.2017

The article examines the works of the Amur region contemporary writers, who use the toposes of such popular genres as detective, science fiction, adventure, sentimental melodrama, romance novel and historical fiction. Using typological, comparative and historical-literary research methods the author shows that the appeal of the Amur writers to the topos of the mass literature genres has been typical of the whole existence of this local literature and explores the novels of the early 20th century and Soviet literature. However, at the turn of 20th-21st centuries, the attention to the topos of the mass literature genres became more intense. Due to this Amur writers update the structure of their texts, expanding readership, using new channels of books' distribution, seeking recognition from literary institutions.

Keywords: genre topos, mass literature, Amur literature, local literary history, the turn of $20^{\text {th }}-21^{\text {st }}$ centuries

DOI: 10.17516/1997-1370-0076.

Research area: philology.

\section{Introduction}

The modern literary process is undergoing serious changes under the influence of the disintegration of the traditional literature supporting system, the emergence of new media, the transforming relationship with the readers. The study of these transformations on the basis of local literary history, correlated with the national literary process, is not only one of the key trends of the modern world in humanities, but also considered one of the leading trends in Russian scientific thought in general.
Amur literature at the turn of the $20^{\text {th }}$ and $21^{\text {st }}$ centuries is of considerable interest here. During this period the Amur region (also known as Priamurye, Amur Oblast and Outer Manchuria) saw the emerging phenomenon of net literature and literary blogging, with the noticeable female writers. Also there appeared joint Russian-Chinese literary collections, new literary almanacs, prizes, literary centers and associations. In this connection, the obvious question arises: how specific are these processes and phenomena? According to the researchers, Amur literature is an inherent part of the all-

(C) Siberian Federal University. All rights reserved

* Corresponding author E-mail address: stonerk@mail.ru 
Russian tradition, which inherits and develops its main trends. For example, A.V. Urmanov, analyzing the genesis of the regional literature, emphasizes the close connection of the literary life in the Amur region with both the literature of the Siberian-Far Eastern region and the literature of Central Russia (Urmanov, 2013: 7). On the other hand, it is possible to speak about the "Amur Text" as "a combination of mythologems and artistic strategies that characterize Amur literature in its historical development" (Krasovskaia, Orobii, 2013: 41). In this study the author is trying to identify the peculiarities of the Amur authors' works as regards genre clichés of mass literature in the context of the "free development" of these very topoi. This free development is characteristic for contemporary Russian literature (Cherniak, 2005: 128).

\section{Statement of the problem}

According to researchers, after 1995, having become free and independent of the state power, Russian literary field practically did not differ "from its Western brethren" (Konstantinova, 2011: 420).

On the cusp of the $20^{\text {th }}-21^{\text {st }}$ centuries, when the postmodern demolishing boundaries between different art types and "floors" in the foreign literature actually ended, it became quite problematic to talk about the confrontation between "high" and "mass" art (Kireeva, 2013: 14). In the situation when literature loses its former borders rapidly and has to share its authority with other media - cinema, radio, TV, the Internet, the creators of the literary product have to think seriously about strategies that will help attract the attention of the modern reader. Any author who chooses their own strategy inevitably encounters a dilemma: the need to find a language that will be understandable to the reader, and yet not lose their own identity. Often, to create effective communication with the reader and update the genre structure, the authors of literary texts resort to the use of mass literature topoi.

It is necessary to clarify the term "topos" in connection with the fact that it has no unambiguous interpretation in modern science. G.K. Kosikov considered topoi as a characteristic feature of traditionalist literature (ancient, old Indian, medieval) (Kosikov, 2011: 4). Under the topoi (or clichés) the scientist meant "a relatively limited set of ideological, figurative, compositional, and alike structures" and emphasized such a property of topos as the ability to correlate any single phenomenon with certain easily identifiable "types" (Ibid, 4-5). Along with lexical, figurative, imaginary topoi, G.K. Kosikov singled out genre topoi (Ibid, 5).

How successful is the term "genre topos" used as a characteristic of certain genre structures and conventions of popular literature? It should be noted that modern researchers use different terms for the popular literature: "literary formulas" (Cawelty, 1976), "automatized genres" (Kent, 1986: 68-78), "genre-thematic canons" (Mel'nikov, 2001: 515), "topoi” (Eco, 2005: 196). In this case, G.K. Kosikov, first of all, attributes the concept of topos to traditionalist literature, which typologically differs from the literature of the New Age (including mass literature as a product of the modern history) (Kosikov, 2011: 5).

However, it seems to us possible to use this term, because the researcher points to the "readymade cultural codes" contained in topoi, with "peculiar semantic, figurative, plot, stylistic, etc. 'clusters', capable of unravelling and deploying" (Ibid, 5-6). This "unravelling and deployment", in our opinion, means that the use of the term "genre topos" allows us to actualize inherent in its structure ability to engage the recipient in a dialogue, thanks to the common zone of interaction and understanding. After all, for many modern authors, the use of genre topoi from mass literature becomes a conscious 
strategy, enabling updating the work's form and carrying out successful communication between the text and the reader (Iauss, 2004: 195).

To what extent are these strategies relevant and specific for Amur authors? The conducted research should help to answer this question.

\section{Under the sign of popularity: the most famous Amur books of the $20^{\text {th }}$ century}

Did the creators of the most popular among Amur dwellers works turn to the arsenal of mass genres earlier? What for, if they did, and in what forms? From the most famous books of the Amur writers, created in the $20^{\text {th }}$ century, we have selected only three that clearly appeal to the mass literature topoi.

Amur bestseller in the early $20^{\text {th }}$ century: the novelette as the era mirror

The collective novel "Amur Wolves", published on the pages of the Blagoveshchensk newspapers in 1912, was called "the bestseller of the century beginning" by the contemporaries (Fedotova, 1996). Having caused considerable interest of the reading public, this scandalous novel was reissued as a separate book 3 times in 1912, 1913 and 1914, and enjoyed the greatest popularity among the Amur readers of the early $20^{\text {th }}$ century (Urmanov, 2012: 13). To a large extent this popularity was based by on the genre choice, the "novelette" as one of the leading genres of both European and Russian mass literature of the $19^{\text {th }}$ century (Ibid, 20).

Researcher A.V. Urmanov distinguishes in "Amur Wolves" such typical for the novelette topois as:

1) Place of action (prison cells, dens, brothels, gambling houses, dwellings of present day rich people),

2) System of characters (the urban "scums", smugglers, miners, bandits (including ethnic ones - honghuzi), thieves, harlots, wealthy fraudulent merchants, corrupt officials),

3) Event canvas (chronicle of urban criminal incidents, financial and property scams, robberies, murders, exciting chases, intensive love passions, pimping, insidious intrigues) (Ibid, 20).

In addition to the typical for the genre topoi, we can also single out such feature, connected with the very existence of a mass product, as its replication in various forms. In the early $20^{\text {th }}$ century, one of such forms, apart from literature, could be a theatrical production. The Amur people enjoyed not only the novel version of "Amur Wolves", but also a play based on its motives, which was staged in Blagoveshchensk with an unprecedented sold-out (Fedotova, 1996: 8-9).

Such popularity of the novel undoubtedly gives the right to see it as a kind of socio-cultural phenomenon, which allows reconstructing events occurring in the Amur region at the beginning of the $20^{\text {th }}$ century, a portrait of the readers, and the ancestral world as seen by today's Amur residents (Urmanov, 2012: 20).

Perhaps, it is this that can explain the reasons for the popularity of "Amur Wolves" not only in the prerevolutionary Amur region, but also among our contemporaries. In 1991, this collective novel saw the light again, first on the pages of the newspaper "Blagoveshchensk", and in 1996 it was brought out in 10,000 copies, though it was a large number for the post-perestroika remote province, the book was sold out in three months.

What attracts modern readers of "Amur Wolves"? Our contemporaries, leaving their feedback on the Internet, identify in the novel the detective topos and admit the fascination of the reading process. But the most powerful element of the novel attractiveness is its being the source of reliable information about the life of the prerevolutionary Blagoveshchensk (see in detail: readers' comments on the novel "Amur Wolves"). 
It is quite obvious that for the modern readers, i.e. not only "ordinary" readers, but also "savvy" ones, "Amur Wolves" are interesting as a kind of documentary evidence about the life in the Amur region. It is no accident, for example, that literary critic A.V. Urmanov, warns against the perception of "Amur Wolves" as simply a "novelette". He notes: "You can also look at the book as in the mirror, reflecting, albeit in a twisted and exaggerated form, what really happened at the beginning of the $20^{\text {th }}$ century in the Amur region (Ibid). Historian N.A. Shindialov points out that the novel reflects the "flair and morals of the then Blagoveshchensk" (Shindialov, 2006: 117). In addition, today's readers, including readersresearchers, are attracted by the opportunity not only to learn about the life of the Amur society a hundred years ago, but also to reconstruct the consciousness of there and then Amur residents: "The work shows what interests and cares they had, what they sought, what they discussed, how they perceived the world around them and their contemporaries" (Urmanov, 2012: 21-22).

Thus, for the modern reader of "Amur Wolves" the "culture trash" (stamps of "tabloid reading") is overlapped by the book's value as an excellent source of information about the life in the Amur region in the early $20^{\text {th }}$ century.

\section{Military historical epic or spy thriller?}

In the Soviet era, it was considered that "mass culture is an attribute of exclusively bourgeois society" (Kostina, 2005: 111). However, this did not abolish the existence of the mass culture in Soviet society, including mass culture following socialist realism.

Writers have long been paying attention to this phenomenon. For example, back in 1956, Vladimir Nabokov, in his lecture "Russian Writers, Censors, and Readers", identified the similarities between the strategies of a "gifted Soviet writer" and the author of a "banal detective" (Nabokov, 1996: 9). And the Croatian writer Dubravka Ugrešić in the essay "Long Live Socialist Realism!" (1996) draws a parallel between the works of socialist realism and mass literature: "Modern market literature $<\ldots>$ is socialist realistic" (Ugrešić, 2000: 5).

Modern researchers confirm that the aesthetics of socialist realism is close to the aesthetics of mass literature. Moreover, the Soviet culture itself can be perceived as a mass one, which "in an accessible and attractive form created an ideal image of the future person and society" (Kostina, 2005: 111). However, unlike bourgeois mass culture, oriented to commercial success, at the core of the Soviet culture there was the ideological dominant, while agitation and propaganda were its main functions (Ibid, 120).

At the same time, the Western mass literature genres, i.e. adventure novel, detective, fantasy, melodrama, were declared bourgeois, and instead of them, there were created their "Soviet" versions, approved of authorities.

In our opinion, the elements of such "reshaped" mass genre topoi can be found in the work of Amur writer Andrei Golovin - "Rear - front" (1958-1960, 1963). This novel was published twice, and for the second time the circulation of 100,000 copies became unprecedented for the Amur publishing house!

The novel is the epic work about the Soviet-Japanese war, when the Far Eastern rear simultaneously acted as a war front, too. According to the researcher V.V. Gus'kov, the book achieved tremendous popularity, despite the obvious shortcomings caused by "Golovin's following norms of socialist realistic aesthetics" (Gus'kov, 2013: 109). It is the canon of socialist realism which determines a system of characters, characters nature and the main conflict of the work.

In our view, it is precisely following the canon of socialist realism that allows Golovin 
to organically include in the novel such topoi of popular literature as spy thriller.

It is worth mentioning that this genre topos turned out to be very popular in the USSR in the early 1930s when the canon of the Soviet spy detective was constructed. It was built on the plot of the state's struggle for absolute ideological power and this vividly represented the ideology of the totalitarian era. In the 1950 s, especially during the "thaw" period, there appeared translations of "entertaining" Western literature, including detective and spy novel. All these factors were combined with the writer's own experience, who being the head of the intelligence school participated in the Soviet-Japanese confrontation during the Second World War. So all these facts contributed to the successful inclusion of the spy thriller topoi in the structure of the Golovin's epic.

The "spy" component of the novel is connected with the figure of Soviet intelligence officer Viacheslav Liubimov. Liubimov's opponents and comrades are not only saboteurs from emigrant intelligence schools and their Japanese curators, but also the American resident Svenson who appeared in the middle of the novel, successfully re-employing both Russian emigrants and Japanese officers.

One of the plot devices, which gives the drama special effect and actualizes the "espionage" topoi, is the description of the terrible activity of the infamous Japanese "Detachment 731", which created and tested bacteriological weapons on humans.

The first book of the novel "The Dead Stripe", dedicated to the confrontation between the USSR and Japan during the World War II, contains a lot of episodes, created according to the laws of the spy thriller. Here there is a description of the work of Intelligence Schools in China, numerous episodes of crossing the Russian-Chinese border, diversions conceived by the USSR enemies, and the successful hunt for spies and their disclosure by Soviet people. In general, the first book is characterized by a topic developed in the framework of the Soviet spy detective of the 1930s.

In the second book "Rapid Attack", describing the military operations of the Soviet Army aimed at liberating China from the Japanese invaders, the number of spy topoi decreases and their specifics change. It is in the second book where the image of the active activity of the American intelligence agent recruiting agents among the White Guard emigres and the Japanese military comes to the fore. It is no coincidence that in the 1950s, when the main centers for confrontation between the two superpowers were formed, and when a new image of the enemy, a representative of Soviet intelligence, appeared in the Western spy novel, the literature of the USSR gave its adequate answer, portraying the resident of American intelligence. And the topic of the Soviet spy novel begins to resemble novels about James Bond with such characteristic elements as the use of oppositions (characters and values); game, including game elements at the narrative level; Manichaean ideology; literary allusions, fascinating plot (Eco, 2005: 237-286). Comparison of the Golovin's novel structure with the Fleming's novels structure seems to us a promising research task.

It is noteworthy that when Golovin was working on the second part of the novel "Rear Front", which became a phenomenon in Amur book publishing, at the same time he was preparing to publish the text of the science fiction novel "Amphibia-2". This author's aspiration to use the genre topoi, which do not correspond to the canon of the socialist realistic novel, and the simultaneous adherence to the socialist realistic aesthetics, in our opinion, allowed the author to find a new formula for success among the readership. 
"Grandfather Biankin - Private Detective"

by V. Letsik: a detective game

While Golovin's novel was created in an epoch when mass literature was recognized as an attribute of bourgeois society and was rarely available to readers, Vladislav Letsik's short novel "Grandfather Biankin - Private Detective" came to readers and became one of the most famous and favorite works of Amur residents in 1970-1980s. It was first published in a regional newspaper (1975) and then in literary and artistic almanac "My Priamurye" (1977), next in 1984 it was reprinted in the collection of stories and tales "A Pair of Paw-Shaped Mukluks". The circulation of 15 thousand copies was sold very quickly. In 2015, the story again appeared in the book "The Inspector of the Eastern Hemisphere".

A.V. Kostina characterizes 1970-1980s in the USSR as the period of the "real boom of mass culture", when the Western mass culture began to exert an active influence on the ideology and aesthetics of the previously closed Soviet society (Kostina, 2005: 122). As a result, the repertoire of genres was substantially updated, and melodrama, detective, historical film became very popular (Ibid, 121).

V. Letsik works with the detective genre topoi, while creating his story. Remembering his work process, the author not only stressed the genre specificity of the work ("detective story"), but also showed how the format of the first publication on the pages of the periodical helped to strengthen the readers' interest through the use of the detective-specific plot devices (Letsik, 2015: 409).

The perception of the reader who did not immediately correlate the "private detective" with the tradition of detective literature, was unobtrusively directed by the author from the first chapter, where the storyteller meets a creator of the "detective autobiography" (Ibid, 11). Joint efforts of the reporter and the author of "The
Mystery of the Old Boot" helped to reconstruct a "tangled story" (Ibid, 9) about the gold found and again lost, whose hero is Grandfather Biankin. The book contains the key detective topoi: 1) the character of the detective, 2) the investigation process, 3) the solution of the puzzle (Kireeva, 2013: 180).

However, according to researchers, the genre of Letsik's story is difficult to be called a detective unequivocally. O.N. Filitova, looking into the writer's characteristic detective signs, finally has to admit that the writer creates a "completely unusual detective work", where the main character "unravels a non-existent crime", the detective's actions violate all the laws of logic, and the criminal turns out to be an assistant detective (Filitova, 2011: 110-111). This makes the researcher conclude that "rather than a detective, we have its parody" (Ibid, 111).

However, the knowledge of the works characteristic of the detective genre makes it possible to ascertain that the disclosure of a non-existent crime, the absence of logic in the detective's actions, and the detective assistant in the role of a criminal do not always testify to the parodying of the detective topoi, but act as full elements of new models of the detective genre being a result of the classic detective transformation (Kireeva, 2013: 178-192).

The writer himself admits that he did not intend to parody detective as a genre, moreover, he was familiar with the genre model in the most general terms only. In addition to the works of A. Conan Doyle and J. Simenon, the author's reading interests included the detective works of the American writes, translated at the time, and the "Adventures of Major Pronin" read in 1950s (Letsik, 2016).

The detective topoi, easily identifiable in Letsik's story, serve as an artistic task, which the author stated as "to involve the reader in the game" (Letsik, 2016). According to the author 
of "Grandfather Biankin", it was important for him not to mock the detective story, but to draw attention to the northern nature, to people living in one of the remote areas of the Amur region with the help of this genre: "It was important to convey the atmosphere of that life" (Ibid).

Author's orientation on the game, as the researchers recognize, is one of the key characteristics of the Letsik's creative manner (Zabiiako, 2010: 105). Together with the author's inclination to "negotiate" with the reader about the "interpretation code" (Ibid, 106), this "game principle" of poetics helps to attract and retain reader interest, so that the "ordinary" and "savvy" readers instead of focusing on the detective's plot, think over serious issues of human life. So, S.I. Krasovskaia discerns Letsik's work a reflection of the problem of loneliness and alienation of the modern man (Krasovskaia, 2013: 227), and the anonymous Internet reader leaves the comment that this book is "about the beauty and richness of the Amur nature, about how representatives of small-numbered peoples (Evenki, Yakuts) live side by side with Amur oldtimers, and newcomers" (Readers' comments on V. Letsik's book "Grandfather Biankin - Private Detective").

The fact of plagiarism, which took place in 2009, when a certain Anton Mel'nikov, having changed the name of the Letsik's hero, published on the Internet a detective entitled "Grandfather Chukhrai - Private Detective", is a kind of evidence of the story's recognition by a modern reader. In 2014, the story of plagiarism became known, heightening interest in "Grandfather Biankin" (Discussion of the Letsik's book plagiarism).

Another evidence of recognition was when in $1985 \mathrm{~V}$. Letsik got a regional version of the Lenin Komsomol Prize for the collection with the detective story. And in 2016, the book "The Inspector of the Eastern Hemisphere" (which included "Grandfather Biankin") was awarded twice, one important award was in the field of literature and art of the Amur Region and also the book got the first literary prize named after Leonid Zavalniuk.

Summarizing the analysis, we conclude that the popularity of the books mentioned were different, because these works are products of different socio-cultural epochs that are in charge of creating and heightening the readers' recognition of "Amur wolves", "Rear - Front", "Grandfather Biankin". What, then, do the three books have in common? In our opinion, for authors of these works, the appeal to the mass literature topoi is not a single fact, but rather an organic interest, co-natural with their creative talent. So, for example, one of the main authors of the novel "Amur Wolves" Alexander Matiushenskii was also the creator of texts with a similar genre model - novels "Counterfeit Onehundred Notes" (1913) and "Mutual Bank" (1916). Andrei Golovin tried his hand at fantasy, creating a science fiction novel "Amphibia-2". Vladislav Letsik after "Grandfather Biankin" created an adventure suspense story ("A Pair of Paw-Shaped Mukluks").

\section{A turn to the genre topoi of mass literature during reforming the literary space}

The period of the late $20^{\text {th }}$-early $21^{\text {st }}$ centuries is designated by us as "reforming literary space" (Kireeva, 2015a: 54). Why "reforming"? In the 1990s the system of literary institutions that had been formed over the decades of the existence of the Soviet system was destroyed. But almost immediately began the process of forming new ways of preserving and promoting literature (including the emergence of new writers' unions, literary newspapers and almanacs, literary prizes, centers for local regional study, local lore conferences, etc.). This led to the emergence of 
significant cultural phenomena in the regional literary space (Ibid, 57-59).

One of the notable writing strategies of this period was turning to the arsenal of mass literature. While in the Soviet era the detective, espionage novel, adventure suspense novel topoi were the most attractive for writers, at the turn of the $20^{\text {th }}-21^{\text {st }}$ centuries, Amur writers started to use a more diverse palette of genre topoi: detective, action movie, fantasy, melodrama, love story, career novel, detective fiction, costume-historical novel and even Christmas story.

For example, the mass literature topoi from the popular in Russia in the second half of the $19^{\text {th }}$ century genre of Christmas story was used by Boris Ivanovich Chernykh (1937-2012), one of the most outstanding writers who put Amur literature in the national context. As N.N. Starygina proves, in the second half of the $19^{\text {th }}$ century within the framework of the Christmas story genre two trends clearly became apparent:

1) the creation of "fashionable" samples of this genre, which appealed to a "mass reader" and transformed into "primitive reading" as a result;

2) Realistic tradition of creating Christmas stories in the context of "great literature" (F. Dostoevsky, N. Leskov, A. Chekhov, V. Korolenko) (Starygina, 1994: 119).

Having created in 2002 story "Grishunya's childhood", B.I. Chernykh continues, in our opinion, the tradition of realistic writers, firmly inscribing her story in the context of Russian classical literature. Thus, referring to the once popular genre and creating its modern version, the author, in fact, opposes her experience to the active use of modern mass genres' topoi.

Another context in which one can analyse the story "Grishunya's childhood" is children literature. In the Amur literature at the turn of the $20^{\text {th }}-21^{\text {st }}$ centuries using the models of mass children literature is quite often. Readers are offered poems, fairy tales, adventure novels. For example, a whole cycle of works for children was created by A. Padalko, who focused on Soviet children poetry topoi, and adventure story for children topoi as well. For example, the typical elements of the plot, the characters, the problems inherent in both the foreign "literature for boys" (the works of M. Twain, for example) and the Soviet children stories (A. Rybakov and others) are recognized in Padalko's adventure story "The Terrible Dungeon Secret" (2000). Written in coauthorship with A. Sivuda novel "The Eighteenth Brother" (2012), whose genre the authors defined as "a detective novel with elements of fiction", also involves the young reader in unraveling mysterious events. Referring to these topoi, in our opinion, is explained by those tasks of literary creativity, which, by researcher-ethnographer V.V. Gus'kov, the writer sets, trying to interest the children, to involve them in understanding the mysteries of the surrounding world and the creative process of invention (Gus'kov, 2013: 296). It is not by accident that the same author took up creating popular science and educationalmethodical books, such as "Problems and Exercises for the Development of Students' Creative Imagination" (1985), "Inventor's ABC" (2001).

Among topoi, which have attracted Amur authors, there has always been fantasy. Its elements are often found in the books of writers working beyond fantastic mass literature genre, those who refer to sci-fi and fantasy as literary devices. But there are writers, for whom the science fiction topoi become dominant, defining the specifics of their creative self-expression. Galina Belianicheva (1940-2014) can be attributed to such authors. Remaining utterly concrete in the creation and depiction of plots and heroes, using the Amur material, the writer complicates the realistic situations of her books with fantastic assumptions. So, in the story "Fantastic Duet" (1994), the main character becomes the owner 
of the elixir that prolongs life. The boy Alyosha from the story "Grandfather's Watch" (1990) goes to the magical realm, located at the North Pole, in order to help the grandfather. In the story "Leaving Pass from the Other World" (2011), the heroes who have returned from the realm of death try to understand the realities of today's life. In the story "Birch Forest" (2011) there arises a question of time travel. In the story "The City of Titanopol" (2011), the plot is connected with the release of chained titans kept in the dungeon.

As a rule, the plot topoi and the situations of Belianicheva's books were repeatedly used by the Russian science fiction earlier, which, according to S.P. Orobii, made the author's works understandable and popular among a wide range of readers (Orobii, 2013: 64). As wide as possible, given that the circulation of the writer's books, published in the difficult years of "reforming the literary space" is far from big.

As already noted above, the Amur writers often turn to different types of sci-fi, using, among other things, the synthesis of genre topoi from mass literature. For example, in 2016, a novice writer Vitaly Ostanin published the story "Osteria 'Old Horse", being rated on book sites as "detective fiction", "fantasy", "Russian fantasy", "modern detective". The book fantastically interweaves topoi from fantasy, detective, spy thriller and alternative history.

It is not only the tendency to synthesis of different genre topoi that is extremely common in modern mass literature, but also the way in which "Osteria 'Old Horse" comes to the reader, since this is an e-book that is downloaded on the websites of "LitRes", "Ozon" and "Amazon". Amur book publishing in the region with a high percentage of migration and population decline has long ceased to make a profit, paper copies of the Amur writers works do not get any opportunity for widespread replication and mass distribution, and such a format for the literary text existence as created with the help of Ridero intellectual publishing system can ensure Ostanin's book a wide audience, not limited by the region's inhabitants. Meanwhile, the writer, who conceived a series of books, began his work on the second story.

Very attractive for the Amur authors are different versions of the historical genre topoi, from costume historical novel to historical fiction. One of the most striking projects in this area is the Stanislav Fedotov's trilogy about the activities of Count N.N. Muravyov-Amursky: "The Return of the Amur" (2008), "The Battle for the Amur" (2011), "Bell Toll from the Amur" (2013). The novel trilogy was preceded by the creation in co-authorship with Valentin Krylov of the screenplay "Eastern Empire" (1999). Having failed with the screen adaptation, Fedotov wrote a trilogy that attracted not only Amur, but Russian readers in general, thanks to the publication of books in several thousand copies in the Moscow publishing house "Veche" (the books have been reprinted several times so far). In our opinion, Fedotov's novels about N.N. Muravyov-Amursky are not exhausted by genre topoi of historical fiction, as they "use historical material to create entertaining plots" and manipulate historical events for the myths' creation (Cherniak, Cherniak, 2015: 66). These books are much broader than the limits set by historical fiction genre. However, it is remarkable that in 2013 the Fedotov's trilogy, created within the framework of the mass historical fiction, whose founder in Russia is V.S. Pikul (Ibid), was awarded the International Prize named after V.S. Pikul. I think this is due to the specifics of the trilogy, where the historically authentic content is transmitted by the plain and popular artistic language.

While the detective, fantasy, adventure, historical narrative topoi in the Amur literature were used long before the period of reforming 
the literary space, the female melodrama with elements of love story and "career novel" came to the Amur reader at the turn of the $20^{\text {th }}$ and $21^{\text {st }}$ centuries. And here the most vivid example of such prose is Gul'chera Bykova's works. The writer's stories and essays came out on the pages of the Amur periodicals in the late 1990s and early 2000s; in 2012 her novel in stories "Nika from the Capricornus Constellation" and in 2015 a collection of short stories and tales "My River's Banks" were published.

A kind of code to understanding the writer's prose may be folklore (Kireeva, 2015). At the same time, readers identify in Bykova's texts not only the folklore origin, but also models of modern mass literature, such as sentimental melodrama, detective, adventure story, love story and even "career novel". It seems that this is not a mere coincidence. Contemporary researchers conclude that mass culture can be considered as the "latest industrial folklore modification" (Zenkin, 2003: 157); they write about the proximity of "poetics and social functions of folklore and mass literature" (Cherniak, 2008: 7).

Most vividly, the mass literature topoi manifest themselves on the plot level and in the characters creation. Creating her characters, G. Bykova overcolours, dramatizes, clearly divides the characters into positive and negative ones, often she only outlines a memorable but superficial image of the character. The world in the Bykova's prose often demonstrates a contrasting opposition of two principles: evil and good, black and white, sad and joyful.

Especially indicative in this respect is the novel "Nika from the Capricornus Constellation", describing the hard lot that fell on the main heroine - Gulnara. Despite the adversity, the heroine does not lose her irrepressible curiosity, endures hardships and remains the winner in the most difficult everyday circumstances, while preserving humanity, compassion, diligence and faith that "the world does have good people".

In "Nika from the CapricornusConstellation", the writer skillfully combines elements of the Western female novel, "career novel" with modern Russian models of "new women's prose", in which, according to researchers, the heroine's professional success is often more important than personal happiness (Ibid, 7).

Bykova's prose enjoys constant popularity with the readers of different ages due to the fact that she represents contemporary ideas about women's identity (Readers' reviews on Bykova's works). But the writer's books are no less interesting to the male audience (Readers' reviews on Bykova's works). No wonder that the editor who was preparing the novel "Nika from the Capricornus Constellation" for publication, commented the book's fate as such: "The rare work of the Amur author had such a readers' success. I often heard reviews: they say like I opened a book in the evening and closed only in the morning, I could not tear myself away" (Bykova, 2015: 4).

In addition to the fact that the considered phenomena of Amur literature at the turn of the century were popular, they also found support from literary institutions. For example, as mentioned above, Vladislav Letsik won three important Amur awards. In 1994, Galina Belianicheva received a literary award named after Grigory Fedoseev for her novel "Fantastic Duet". In 2013, S. Fedotov, the creator of the trilogy about Earl Muravyov-Amursky, became a laureate of the International Prize named after V.S. Pikul "For the development of the Russian historical novel traditions" (2013). Alexey Padalko is a laureate of the Amur Prize in Literature and Art and the Prize named after Pyotr Komarov. In 2017, the historical trilogy of S. Fedotov and the book "My River Banks" by G. Bykova will be nominated for the Leonid Zavalniuk literary prize. 
However, it cannot be asserted that these works, which are oriented on genre topoi of detective, fantasy, adventure, sentimental melodrama and so on either explicitly or implicitly, correspond to the main parameters of mass literature. The only exception, in our opinion, is the work of Viacheslav Valer'evich Rybakov, who publishes his books under the pseudonym "Stanislav Rem". Viacheslav Rybakov was born and grew in Blagoveshchensk, graduated from the Pedagogical Institute, but so far he has lived in Kiev for 30 years, at the same time he does not lose links with the homeland: his books are published in the Amur Region, the essays and memoirs are printed in the BSPU literary almanac "Amur". Although the subject of his prose is much broader, Rem's novels are dedicated to the revolutionary events in Petrograd, the mysterious episodes of the World War II, and the vicissitudes of the "Orange Revolution" in Ukraine.

S. Rem uses Amur material when creating three novels from the series "Provocation". In 2009 in Blagoveshchensk he published the novel "The Simple Chessboard", based on the events of the Russian-Chinese armed conflict in 1900. In 2013, this novel was republished in the Moscow publishing house "Veche" under the title "Over the Quiet and Dark River". And then the publishing house released another Rem's "Amur" novel, "The Missing Expedition" with elements of science fiction and detective, where the events of the Soviet past are intertwined with modernity, and the sources include not only the real memories of the Amur archeology patriarch B.I. Sapunov, but also the research of the Alternative History Laboratory of the "Third Millennium Foundation". Another novel from the Amur series "Taking into Account", dedicated to the aggravation of relations with the PRC after the conflict on Damansky Island in 1969, was published in the same publishing house in 2014.
Publishing novels in the capital, the author managed to attract a wider range of readers not only through the synthesis of several mass genres topoi, but also through referring to the exotic material for the general Russian readers, namely the mysterious and enigmatic events in the distant Amur province. This material in the author's interpretation can influence not only the fate of the whole Russia (the novels "Over the Quiet and Dark River", "Taking into Account"), but also the lot of human civilization ("The Missing Expedition").

All Rem's published novels fully correspond to the characteristics of the mass literature:

1. The author works with topoi of such mass genres as adventure novel, detective story, fantasy. This feature of books also draws the authors of online reviews (Readers' Reviews on Stanislav Rem's books). In this regard, we will assume that among the comments on Rem's books on the Internet there are those written by the author himself, representing himself as a certain reader from Blagoveshchensk. We compared the reviews posted on various Internet sites and found a literal match in the characteristics of this writer's books made by users "Vladimir" and "ushakov", who left reviews only on Rem's books (Readers' Reviews on Stanislav Rem's books). These texts represent a kind of "clues" to the reader, as they indicate in what genre tradition it is worthwhile perceiving the presented works. While the authors of other reviews characterized the genre of books laconically as "detective", "fantasy", "adventure", "Vladimir" - "ushakov" gives more detailed genre definitions ("intellectual detective", "retro detective", "romantic detective in the spirit of Akunin", "political detective", "science fiction"). In addition, this reviewer tunes the reader's perception, placing Rem's works in typological series popular with both Soviet and modern Russian readers (Ibid). 
2. The difference in the estimates made by "professional" and "ordinary" readers. So, anonymous Internet reviewers write about whether the author carries the reader away with the plot peculiarities, whether the book was easy to read or, on the contrary, "boring", and generally give positive feedback to the work (Ibid). Literary critic Irina Nazarova describes the novel's main advantage - "exciting plot" as a characteristic of adventure genre. Also she pointed out the book's defects, such as textual inaccuracies, too free interpretation of prototype figures, the lack of individual characters, in return for which the author represents "types" of truth-seekers and bandits (Nazarova, 2015: 80). That is the point, which is a characteristic feature of mass literature with its high standardization.

3. The author's works are characterized by seriality, including author's series (the cycle "Provocation"), and publishing ones ("Secret Fairway", "Siberian Adventure Novel”, "Sibiriada") (Cherniak, Cherniak, 2015: 150).

4. Relatively large circulations $(3,000$ copies), which are bought up (on the Internet sites a whole series of books are marked as 'absent') and again reprinted.

5. Game with the audience, the author works under a pseudonym (Ibid, 7; 134), which, incidentally, helps not to confuse Rem with the famous science fiction writer Viacheslav Mikhailovich Rybakov. Also, the author uses mass genres formulas, being a professional in the field of literary criticism (Rem-Rybakov teaches at the Kiev Slavic University).

6. Distribution of books in different formats: in paper, electronic versions, as well as online on specialized book sites.

Thus, we were convinced that modern Amur writers are actively turning to genre topoi of mass literature, embodying in them dissimilar author's intentions and achieving different results. Among the latter, one can also name new channels for book distribution, expanding audience, and recognition by certain literary institutions (facts of nomination and awarding of literary prizes, inclusion of regional literature in the research pool).

\section{Conclusion}

So, analysis of Amur authors' attention to the genre topoi of mass literature allows us to conclude that this process is not specific for the turn of the $20^{\text {th }}$ and $21^{\text {st }}$ centuries: in Amur literature there is a significant tradition of using mass genres topoi, such as "novelette", spy novel, fantasy, detective, and adventure novel.

Yet, at the turn of the century, during the literary space reforming, the use of mass genres topoi happens on the ever larger scale and allows writers to solve different tasks, including drawing readers' attention to their work, experimenting with the possibilities of the genre form, finding and approving their own artistic style and so on and so forth. In this period, one can witness the expansion of the genre arsenal of topoi used (sentimental melodrama, career novel, Christmas story, fantasy, historical fiction), the use of new distribution formats (e-book, online reading on specialized book sites), active communication between the author and a reader in the Internet space.

It is important to admit that the strategy chosen by writers brings its results: in the context of regional publishing decline combined with a large outflow of population, the authors gain new opportunities for expanding the readership, new channels of distribution, recognition by literary institutions. However, such a strategy also turns negatively, sometimes it is accompanied by decreased text quality.

In general, it is necessary to acknowledge that the strategy of using genre clichés of mass literature is in line with those trends that characterize the Russian modern literary process. 
However, due to the regional specific features and the associated state of regional book industry, there is a paradoxical situation is created when the mass literature works do not have large circulation and broad audience. Perhaps, it is thanks to this that the Amur writers manage to preserve the "uncommon countenance"1 without plunging into the popular literature genres.

Expression from the verse "Muse" by E. Baratynsky.

\section{References}

Bykova, G. (2015). Berega moei reki. Povest', rasskazy [My River's Banks. A tale, stories]. Blagoveshchensk, "Tsarskoe slovo", $252 \mathrm{p}$.

Cawelty, J. G. (1976). Adventure, Mystery and Romance: Formula Stories as Art and Popular Culture. Chicago.

Cherniak, M.A. (2005). Fenomen massovoi literatury XX v. [The phenomenon of mass literature of the $20^{\text {th }}$ century]. Saint-Petersburg, RSPU named after A.I. Herzen, $308 \mathrm{p}$.

Cherniak, M.A. (2008). Massovaia literatura kontsa XX - nachala XXI veka: tekhnologiia ili poetika? [Mass literature of the late $20^{\text {th }}$ - early $21^{\text {st }}$ centuries: technology or poetics?], In Filologicheskii klass [Philological Class], 20, 4-11.

Cherniak, V.D., Cherniak, M.A. (2015). Massovaia literatura v terminakh i poniatiiakh [Mass literature in terms and concepts], In Uchebnyi slovar'-spravochnik [Educational reference dictionary]. Moscow, Flinta, Nauka, 192 p.

Chitatel'skie otzyvy na knigi Bykovoi [Reader's comments on Bykova's books], available at: http:// www.proza.ru/2013/04/08/511, http://www.proza.ru/avtor/gulchera (date of access: 16.12.2016).

Chitatel'skie otzyvy na knigi Fedotova [Reader's comments on Fedotov's books], available at: https://www.livelib.ru/author/351682-stanislav-fedotov, http://www.labirint.ru/books/383903/ (date of access: 17.12.2016);

Chitatel'skie otzyvy na knigi Rema [Reader's comments on Rem's books], available at: https:// www.livelib.ru/book/1000741038/reviews-propavshaya-ekspeditsiya-stanislav-rem, http://www. labirint.ru/reviews/goods/419150/, http://litlife.club/bd/?b=238682 (date of access: 16.12.2016).

Chitatel'skie otzyvy na knigu V. Letsika "Ded Biankin - chastnyi syshchik" [Reader's comments on V. Letsik's “Grandfather Biankin - Private Detective”], available at: http://www.libamur.ru/ fotorussiachina/4332.html;http://xn--blacd3balk.xn--plai/knigoman/item/3755-ded-byankin-chastnyjsyshchik-vladislav-letsik-2015-g (date of access: 11.12.2016);

Chitatel'skie otzyvy na roman "Amurskie volki" [Reader's comments on the novel "Amur Wolves"], available at: https://books.google.ru/books?id=YYcoAAAACAAJ\&hl=ru\&sitesec=revie ws; http://soyuz-pisatelei.ru/board/42-1-0-106 (date of access: 04.12.2016);

Eco, U. (2005). Rol' chitatelia. Issledovaniia po semiotike teksta [The role of the reader. Explorations in the semiotics of text, transl. by. S.D. Serebianyi]. St. Petersburg, Symposium, 502 p.

Fedotova, O. (1996). Bestseller nachala veka [Bestseller of the beginning of the century], In Amurskie volki: Kollektivnyi roman iz zhizni Priamur'ia [Amur wolves: A collective novel from the life of the Amur region], 5-13. Blagoveshchensk, available at: https://cloud.mail.ru/pub lic/3HyGRguMhuWd/\%D0\%90\%D0\%BC\%D1\%83\%D1\%80\%D1\%81\%D0\%BA\%D0\%B8\%D0 $\% B 5 \% 20 \% D 0 \% B 2 \% D 0 \% B E \% D 0 \% B B \% D 0 \% B A \% D 0 \% B 8 . \% 20 \% D 0 \% 9 A \% D 0 \% B E \% D 0 \% B B$

$$
-697-
$$


$\% D 0 \% B B \% D 0 \% B 5 \% D 0 \% B A \% D 1 \% 82 \% D 0 \% B 8 \% D 0 \% B 2 \% D 0 \% B D \% D 1 \% 8 B \% D 0 \% B 9 \% 20$

$\% D 1 \% 80 \% D 0 \% B E \% D 0 \% B C \% D 0 \% B 0 \% D 0 \% B D \% 20 \% D 0 \% B 8 \% D 0 \% B 7 \% 20$ $\% D 0 \% B 6 \% D 0 \% B 8 \% D 0 \% B 7 \% D 0 \% B D \% D 0 \% B 8 \% 20 \% D 0 \% 9 F \% D 1 \% 80 \% D 0 \% B 8 \% D 0 \% B 0 \% D 0$ $\% B C \% D 1 \% 83 \% D 1 \% 80 \% D 1 \% 8 C \% D 1 \% 8 F$.docx (date of access: 6.12.2016)

Filitova, O.N. (2011). Naskol'ko detektivna "detektivnaia povest' ” V. G. Letsika "Ded Biankin chastnyi syshchik" [How detective is V. Letsik's "detective tale" - "Grandfather Biankin - Private Detective"], In Problemy khudozhestvennogo miromodelirovaniia v russkoi literature [Problems of artistic world-modeling in Russian literature], 10, 100-111. Blagoveshchensk, BSPU.

Gus'kov, V.V. (2013a). Golovin Andrey Andreevich, In Entsiklopediia literaturnoi zhizni Priamur'ia XIX-XXI vekov [Encyclopedia of literary life in the Amur region in the $19^{\text {th }}-21^{\text {st }}$ centuries], 108-110. Blagoveshchensk, BSPU.

Gus'kov, V.V. (2013b). Padalko Alexey Egorovich, In Entsiklopediia literaturnoi zhizni Priamur'ia XIX-XXI vekov [Encyclopedia of literary life in the Amur region in the 19th-21 st centuries], 296-297. Blagoveshchensk, BSPU.

Iauss, G.R. (2004). Istoriia literatury kak vyzov teorii literatury [History of literature as a challenge to the literature theory], In Sovremennaia literaturnaia teoriia [Modern literary theory]. Anthology. Moscow, Flinta, Nauka.

Kent, Th. (1986). Interpretation and Genre - The Role of Generic Reception in the Study of Narrative Texts. Toronto.

Kireeva, N.V. (2013). Postmodernistskaia literature SShA: Osobennosti zhanrovoi poetiki [The USA postmodern literature: Features of genre poetics]. Blagoveshchensk, BSPU, 344 p.

Kireeva, N.V. (2015). Rol' fol'klornogo nachala v proze Gul'chery Bylovoi [The role of folklore in Gul'chera Bykova's prose], In Filologicheskie nauki. Voprosy teorii i praktiki [Philological Sciences. Issues of theory and practice], 2-1 (44), 104-106.

Kireeva, N.V. (2015a). Rol' literaturnykh institutsii v dinamike literaturnogo protsessa v Amurskoi oblasti vo vtoroi polovine XX veka [The role of literary institutions in the literary process dynamics in the Amur Region in the second half of the $20^{\text {th }}$ century], In Losevskie cteniia - 2015 [Losev Readings 2015], 54-59. Blagoveshchensk, BSPU.

Konstantinova, M. (2011). Peremeny v russkom literaturnom pole vo vremia i posle perestroiki (1985-1995) [Changes in the Russian literary field during and after perestroika (1985-1995)]. Amsterdam.

Kosikov, G.K. (2011). Sobranie sochinenii. T. 1: Frantsuzskaia literature [Collected works. Vol. 1: French Literature]. Moscow, Tsenter knigi Rudomino, 4-6.

Krasovskaia, S.I. (2013). Letsik Vladislav Grigorievich, In Entsiklopediia literaturnoi zhizni Priamur'ia XIX-XXI vekov [Encyclopedia of literary life in the Amur region in the $19^{\text {th }}-21^{\text {st }}$ centuries], 225-228. Blagoveshchensk, BSPU.

Krasovskaia, S.I., Orobii, S.P. (2013). "Amurskii tekst" ["The Amur texet"], In Entsiklopediia literaturnoi zhizni Priamur'ia XIX-XXI vekov [Encyclopedia of literary life in the Amur region in the $19^{\text {th }}$-21 st centuries], 41-42. Blagoveshchensk, BSPU.

Letsik, V. (2015). Revizor Vostochnogo polushariia [The inspector of the Eastern Hemisphere]. Blagoveshchensk, RIO, 416 p., available at: http://ru.calameo.com/read/00280751307656a019688 (date of access: 16.12.2016). 
Letsik, V.G. (2016). Interview to N.V. Kireeva. December 2016, In Personal archive of N.V. Kireeva.

Mel'nikov, N.G. (2001). Massovaia literature [Mass literature], In Literaturnaia entsiklopediia terminov i poniatii [Literary encyclopedia of terms and concepts], 515-516. Moscow, Intelvak.

Nabokov, V.V. (1996). Pisateli, tsenzura i chitateli v Rossii [Russian writers, censorship and readers, Russian translation by A. Kurt], In Lektsii po russkoi literature [Lectures on Russian literature], 5-20. Moscow, Nezavisimaya Gazeta.

Nazarova, I. (2015). Knizhnaia lavka. Obzor khizhnykh novinok (2014-2015) [The bookstore. Review of novelties (2014-2015)], In Amur: Literary almanac of the Belarusian State Pedagogical University, 14, 79-84.

Obsuzhdenie istorii o plagiate knigi Letsika [Discussion of the plagiarism history concerning Letsik's book], available at: http://amur-bereg.ru/threads/ischu-knigu.6690/page-2; http://www. chitalnya.ru/commentary/14096/ (date of access: 12.12.2016)

Orobii, S.P. (2013). Belianicheva Galina Petrovna, In Entsiklopediia literaturnoi zhizni Priamur'ia XIX-XXI vekov [Encyclopedia of literary life in the Amur region in the 19th-21 st centuries], 63-64. Blagoveshchensk, BSPU.

Shindialov, N.A. (2006). Istoriia Blagoveshchenska. 1856-1907. Ocherki, dokumenty, materialy [The history of Blagoveshchensk. 1856-1907. Essays, documents, materials]. Blagoveshchensk, Amurskaia Iarmarka.

Starygina, N.N. (1994). Sviatochnyi rasskaz kak zhanr [Christmas story as a genre], In Problemy istoricheskoi poetiki [Problems of historical poetics], 3, 249-261.

Ugrešić, D. (2000). Chitat' ne nado [Reading is not necessary! Russian trans. by O. Kirichenko]. Moscow: Publishing house of Olga Morozova.

Urmanov, A.V. (2012). "Est' liudi i net ikh...”: Roman "Amurskie volki” kak literaturnyi fenomen ["Once there are people and then there are no...": The novel "Amur Wolves" as a literary phenomenon], In Filologicheskaia regionalistika [Philological regionalistics], 2 (8), 13-28.

Urmanov, A.V. (2013). Ot redaktora [Editor's column], In Entsiklopediia literaturnoi zhizni Priamur'ia XIX-XXI vekov [Encyclopedia of literary life in the Amur region in the $19^{\text {th }}-21^{\text {st }}$ centuries], 5-9. Blagoveshchensk, BSPU.

Zabiiako, A.A. (2010). Liricheskii geroi Vladislava Letsika: homo legens - homo ludens [Vladislav Letsik's lyrical hero: homo legens - homo ludens], In Losevskie cteniia - 2010 [Losev Readings 2010], 97-118. Blagoveshchensk, BSPU.

Zenkin, S. (2003). Massovaia kul'tura - material dlia khudozhestvennogo tvorchestva: k probleme teksta $\mathrm{v}$ tekste [Mass culture - a material for artistic creativity: on the problem of text in the text], In Populiarnaia literature: Opyt kul'turnogo mifotvorchestva v Amerike i Rossii [Popular Literature: The Experience of Cultural Myth-Making in America and Russia], 158-168. Moscow, MSU. 


\section{Жанровые топосы массовой литературы \\ в творчестве амурских писателей \\ на рубеже XX-XXI веков}

Н.В. Киреева

Благовещенский государственный педагогический университет

Россия, 675000, Благовещенск, ул. Ленина, 104

Статья посвящена анализу произведений современных амурских авторов, использующих топосы таких массовых жанров, как детектив, фантастика, приключения, сентиментальная мелодрама, любовный роман, историческая беллетристика. Используются типологический, сопоставительный и историко-литературный методы исследования. Проведенный анализ позволяет сделать вывод, что обращение писателей Приамурья к жанровым топосам массовой литературы не является процессом, характерным только для периода рубежа XX-XXI веков. Однако именно в обозначенный период названный процесс приобретает более высокую степень интенсивности и в иелом соотносится с тенденциями, характерными для российской литературы рубежа веков. Используя жанровые топосы массовой литературы, амурские писатели обновляют структуру своих текстов, расширяют читательскую аудиторию, используют новые каналы распространения книг, добиваются признания литературными институциями. Ключевые слова: жанровый топос, массовая литература, амурская литература, литературное краеведение, рубеж ХХ-ХХІ веков.

Научная спеииальность: 10.00.00 - филологические науки. 